\title{
IMPLEMENTATION OF THE CONTINGENCY PLAN ON OFFSHORE UNITS INCLUDING MOBILE OFFSHORE DRILLING UNITS
}

\begin{abstract}
The article discusses practical application of the contingency plan (called also the emergency response plan) to the risks that may occur on an offshore unit. The author, based on her own professional experience, discusses the plan and illustrates its use in practice based on selected elements of the plan for mobile offshore drilling units engaged in the exploration of resources beneath the seabed. The paper discusses the requirements of Directive 2013/30/EU, which is includes obligation to implement the contingency plan relating to offshore units, in order to prevent accidents resulting from offshore oil and gas operations.
\end{abstract}

\section{Keywords:}

safety of navigation, MODU, contingency plan (emergency response plan).

\section{INTRODUCTION}

The contingency plan (called also the emergency response plan) for shipboard emergencies is designed in accordance with the requirements of the IMO Resolution A.852 (20) 'Guidelines for a structure of an integrated system of contingency planning for shipboard emergencies' adopted on 27 of November 1997, amended by the Resolution A.1072 (28) 'Revised guidelines for a structure of an integrated system of contingency planning for shipboard emergencies' adopted on 4 December 2013. In addition, on board of an offshore unit the Ship Oil Pollution 
Emergency Plan is developed in accordance with the requirements of the Regulation 37 of Annex I of MARPOL 73/78 regarding the requirements of the International Management Code for the Safe Operation of Ships and for Pollution Prevention (ISM Code) in section 1.2.2.2, force the Shipowner (Offshore unit manager) to identify all the risks relevant to offshore platforms and the crew, and some that may pose threats to the environment, as well as to establish adequate safeguards against their occurrence and pursuant to section 1.2.2.3 the Owner is required to ensure continuous improvement of skills of shore side personnel and shipboard personnel in terms of security management including preparation to response to threats, and the eighth chapter of the ISM Code. Safety Management System should provide measures ensuring that the shipowner has the necessary organization, which can react to threats, accidents and emergencies which may occur at an offshore unit at any time.

In addition, the regulations of the Directive 2013/30/EU of the European Parliament and of the Council of 12 June 2013 on safety of offshore oil and gas operations and amending Directive 2004/35/EC of the european parliament and of the council of 21 April 2004 on environmental liability with regard to the prevention and remedying of environmental damage require the development of an emergency response plan and proceeding in case of the exploration of the seabed.

\section{THE PURPOSE, THE STRUCTURE AND IMPLEMENTATION OF CONTINGENCY PLANNING FOR SHIPBOARD EMERGENCIES}

\section{The emergency response plan}

The aim of the emergency response plan is to determine:

- rules for ensuring the preparation of the crew to take immediate action in response to shipboard emergencies;

- procedures, which are necessary to take appropriate actions safely and adequately to counteract the emerging risks or foreseeable threats;

- integration of plans in place in an offshore unit in order to integrate operating plans, so that there are no discrepancies between applicable documents ${ }^{1}$;

${ }^{1}$ For example, on the sea, the following documents have been implemented concerning the works in terms of license to meet the requirements of marine mining:

- mining rescue plan drawn up under the provisions of the Act of 01.30.2015 Geological and Mining Law (Journal of Laws 2015 item 196) Regulation of the Minister of Economy of 12 June 2002 on mine rescues (Journal of Laws No. 94, item 838 of 1 July 2002), as amended; 
- scope of duties, responsibilities, mode of conduct of an sea unit's crew and all persons residing on it during the occurrence of an emergency or its probable occurrence;

- scope of duties, responsibilities, mode of conduct of shoreside personnel involved in responding to emergencies taking place on an sea unit, ways of communication on an sea unit and between an sea unit and members of the crisis response team;

- potential hazards and emergencies and course of action when they occur;

- the speed and effectiveness of response by determining the communication channels for reporting emergencies, day-to-day reporting and actions in the event of emergency;

- alarm signals depending on the type of emergency;

- and to ensure that procedures in the event of emergency will be constantly reviewed and updated and that introducing changes to the plan in order to improve its operational efficiency will be immediately implemented on-board an offshore unit.

The emergency response plan consists of the following components:

- introduction;

- defining the scope;

- planning, preparation of the crew during trainings organised on-board an offshore unit;

- response actions;

- defining the reporting procedure;

- appendices introducing additional patterns/elements to the plan.

- safety and health care document developed in accordance with the provisions of the Geological and Mining Law (Journal of Laws 2015, 196) and related Regulation of the Minister of Economy of 25 April 2015 on detailed requirements for operating the extracting plants mining through the use of drilling (Journal of Laws 2014, 812);

- plan to combat oil spills arising due to mining activities carried out by LOTOS Petrobaltic S.A. in the licence area, coordinated with the 'National Contingency Plan for Marine Spill Incidents with Oil and Other Harmful Substances',

- ship contingency plans to combat marine oil spills developed for each rig, in line with MARPOL Convention, Annex I, Regulation 37;

- management for the safe operation of ships in accordance with the requirements of Chapter IX of 1974 SOLAS Convention. 


\section{The structure of the emergency response plan}

The first two elements of the plan show its key message and indicate who is obliged to comply with its provisions. The rest of the paper presents examples of how the plan can be implemented.

The third element of the plan sets out the principles of planning trainings for the crew to prepare them to act in emergencies, eliminate errors and improve the skills of the crew, taking into account the developments and adapting skills to frequently changing developments. This element of the plan ensures that the crew is acquainted with the plan as a whole, which is at the same time providing the crew with practical information concerning relevant procedures. Taking place on board drills and training will allow every member of the crew to find out ahead of time on what his task and responsibility for their actions and to whom and how to report during intervention. It should be emphasized that the success of such intervention depends on the capabilities of the crew, that is their skills, available rescue equipment, reaction time and other factors, such as prevailing conditions, the source of danger, as well as luck. The shipowner (offshore unit manager) plays the fundamental role, as she/he is responsible for maintaining ship and its equipment in proper condition, conduct proper supervision, correcting defects and shortcomings, as well as carrying out systematic review of offshore unit's condition and reporting such inspections. Depending on the location of the event (location of the unit and accessibility to external rescue services), success of the operation depends on quick notification and arrival of external emergency coordinating authorities.

To ensure continuous improvement of the crew, a schedule of practice alerts and special trainings for the crew is defined ${ }^{2}$. Training sessions must take place at regular intervals, taking into account relevant topics. The commander of the unit must be sure that the crew know the emergency procedures and is properly prepared in the event of a real threat.

Records of all the drills and trainings conducted on the ship and together with the shoreside services or/and the shipowner should be kept and be available for verification. If drills are organised with the participation of external institutions or observers, either party is advised to prepare reports, so that following the drills they could discuss their progress and draw conclusions for the future, as well

\footnotetext{
2 The minimum frequency of exercises, trainings and drills on offshore units is specified in the 1974 SOLAS Convention, and for ships under the Polish flag in Regulation.
} 
as improve emergency procedures. Sample conclusions of the report can include the following: provide the crew with additional means of communication, integrated into fire fighting helmets - it enables a 'hands free' operation while reporting about the progress of the situation, provide the necessary equipment to combat oil spill, appropriately mark containers with equipment to combat oil spill, replace destroyed labels on ventilation flaps, etc.

Joint drills are aimed at ensuring coordination between the crew and representatives of the shipowner and other services, to ensure effective intervention, and also assure that the crew is ready for action.

The fourth element of the plan refers to activities in the state of emergency which has occurred on an offshore unit. It contains procedures for dealing with emergencies, depending on the type and the location of the vessel, i.e., whether it stays in the harbour, or moving on a shipping lane. Potential emergencies are defined in the plan, including other risks - also those not specified therein, to indicate the course of action according to the present situation. The diagram in Figure 1 shows main emergencies along with suitable course of action, depending on turn of events. In addition, depending on the type of ship, the work carried out, or ships location, different emergencies may be identified. For example, for an offshore drilling unit the following emergencies can be additionally identified: eruption, helicopter crash on board or in close proximity, object collision, uncontrolled tilt of the unit.

Regardless of the event, the effects of the intervention must be properly described and taken into account. In an emergency, you should always consider saving lives, protecting the environment and the cargo paramount, in that particular order. This means that initiating activities, which are common to all sea vessels, regardless of the work carried out, should be fully taken into account. In an emergency, the operational standard it is to protect personnel, stabilize the situation and minimize the damage to the offshore unit as well as to mitigate damage to the environment. This procedure should be continuously developed and improved. In terms of prevention or elimination of pollution originating on board an offshore unit or overboard, it is necessary to implement and develop the guidelines recommended by the International Maritime Organization - References to the Guidelines for the development of Shipboard Oil Pollution Emergency Plans (Resolution MEPC 54 (32)), which contain information regarding which instructions apply to the crew during preparation for such tasks for a specific vessel, taking into account its specificity. 


\section{Implementation the contingency plan for shipboard emergencies}

Implementation of the plan takes place on board during training sessions and drills. The plan is publicly available, so that the crew can get acquainted with its contents. Any introduced changes are immediately communicated to the crew, so they can learn about them immediately.

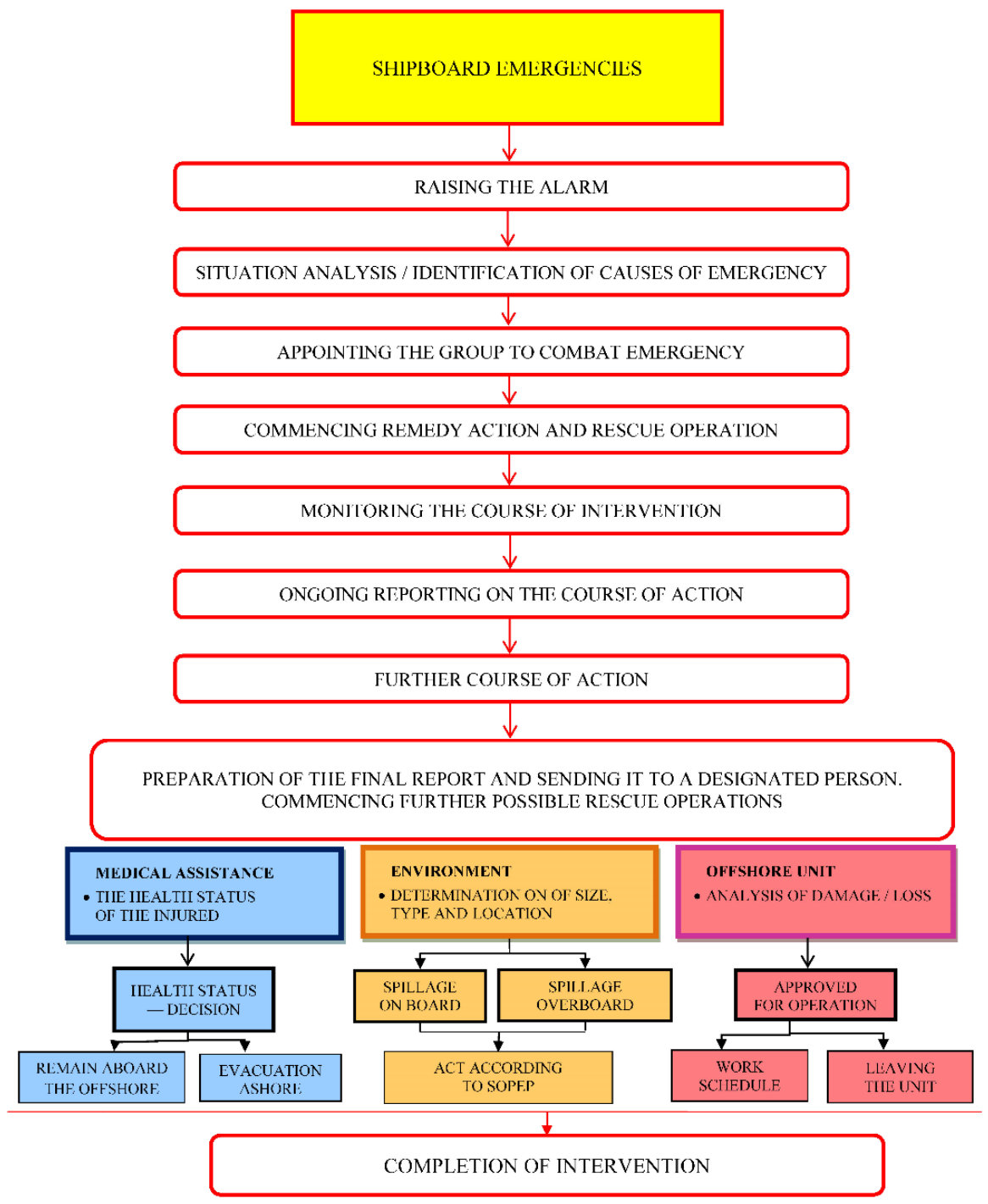

Fig. 1. Potential states of emergency on offshore units 
What is of key importance, the specified course of action must not consist of 'empty' documents, they must include clear guidelines in terms of actions taken in emergency. Such shipboard plans should be identical to those found in the office of the Shipowner and should minimize any discrepancies in case of an emergency, and also define who is responsible for which threat, and all the plans should be clear when it comes to their practical implementation.

\section{Practical examples of the provisions of the contingency plan for shipboardemergencies}

Preparation of the drilling rig crew to act in the states of emergency, carried out during drills and trainings on an offshore unit. Every offshore unit has a defined set of rules regarding planning and organization of drills and trainings.

The aim of the procedure is to determine:

- preparation of the drilling rig crew to operate in emergency that might occur on or within it;

- a schedule for drills and trainings for the drilling rig crew;

- how to arrange and conduct practice alerts on a drilling rig;

- drill schedule between a drilling rig and the office including its organization and its course.

The procedure includes in its scope the actions of an offshore unit's crew and Company's (Manager) representatives, in order to prepare them for shipboard emergencies. The guidelines also include the preparedness of the representatives of the Crisis Response Team and shoreside personnel engaged in responding to emergencies occurring at sea - as a support to the crew in elimination of emergency.

The procedure assigns the responsibility to every person present on an offshore unit. Various positions correspond to different responsibilities. For example, commander of an offshore unit announces the drill depending on the type of hazard, approves the program of practice alerts for a given calendar year, performs supervision over the implementation of the drills and their course, oversees readiness of the crew to act in emergency situations. Any person entering an offshore unit is obliged to: distinguish between types of alarm signals and take appropriate action corresponding to them, participate in organized drills, regardless of the work and rest schedule, demonstrate knowledge of the tasks assigned to emergency numbers contained in the alarm schedule. 
To ensure proper operation in emergency situations, drills, exercises and trainings are organised on every offshore unit according to the alarm schedule. Commander of an offshore unit, taking into account the improvement of safety at sea, has the right to extend the scope of drills and exercises to improve the skills of his crew. A drill is announced through the loudhailer with clear indication that this is a training alarm, so as not to cause panic among the crew. During the drill the procedures, crew skills, technical means and organizational measures necessary to ensure the accuracy of carrying out the alarm and acting in simulated emergency are tested. All the drills are recorded in the logbook together with a short description of the alarm. If it is impossible to carry out an alarm within the designated period, the reasons for such failure should be given, indicating the next proposed time to retry it and make appropriate entries in the unit's logbook.

Figure 2 shows the essence of the drills aboard an offshore unit, that is to improve the skills of the crew in terms of dealing with shipboard emergencies.

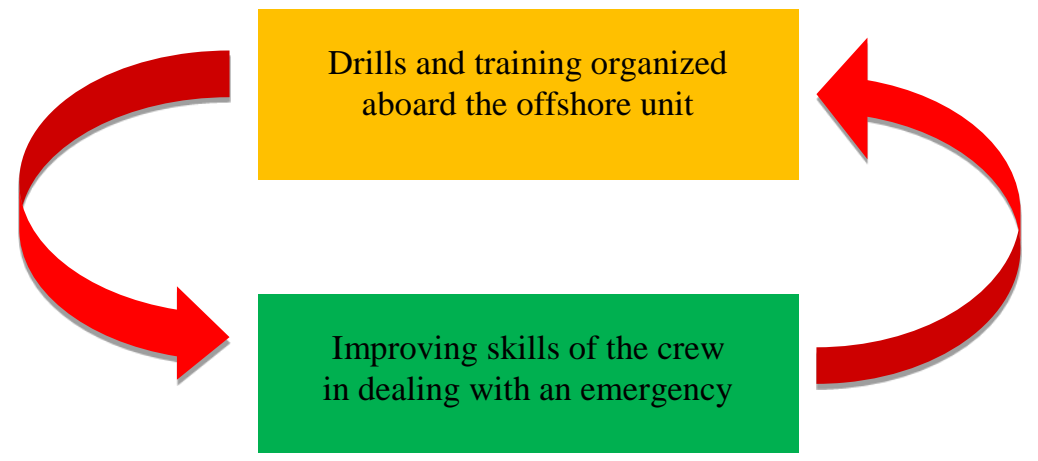

Fig. 2. Purpose of drills organised on board an offshore unit

Another example of the procedures contained in the plan are the rules of conduct during emergency which is likely to occur on an offshore unit.

The aim of the procedure is to identify and define: course of action for the crew and all the persons present on an offshore unit at the time of an emergency, as well as responsibilities and ways to communicate on the unit in the event of an emergency, as well as between the unit and the shoreside services. The procedure includes in its scope the actions taken by the crew in emergencies. To ensure the necessary support from the shoreside during the occurrence of an emergency at sea, the 'Responding to emergencies' procedure was defined. 
The commander of an offshore unit or in his absence - the person appointed to perform his duties - manages the work of the Group in Command in order to eliminate the effects of an incident:

- performs both initial and ongoing assessment of the situation and possible developments;

- manages the information flow;

- decides on further proceedings on the basis of consultations with the people involved in eliminating the emergency;

- manages the entire action;

- supervises the use of resources and funds;

- supports the work of leaders of specialized teams, maintains communication with all the staff working at sea;

- maintains communication and contacts with external parties;

- passes the information to shoreside crisis management services LBP to the extent possible.

To ensure proper operation in the states of emergency the following groups and sections prepared for immediate action are listed in the alarm schedule:

1. The task of Group in Command is to manage and coordinate activities during an emergency at sea and to ensure internal and external communication.

2. Fire Section performs tasks related to the fire fighting and explosions and also those indicated during the evacuation of people from confined spaces.

3. The working group performs tasks depending on the threat and the instructions of the commander of the Working Group. The main tasks include, among others: in case of fire hazard - closing the ventilation, during rescue operation man overboard, persons indicated in the alarm schedule, perform tasks in the field of lowering the boat in the water and taking on board people from water and transporting them to the rescue ship or to the rig, during the alarm - evacuation of people from confined spaces may consist of the team of rescuers entering the confined space.

4. Engineering group performs tasks including: servicing machinery, main engines, emergency power supplies and according to the instructions issued by the Commander depending on the type of hazard.

5. Boat group performs tasks in accordance with the number assigned in the alarm list, including: ensuring readiness of boats to free-fall and other rescue measures, and associated with verification of the presence of the crew and transfer of headcount to Group in Command. 
6. Operation Section performs tasks related to safety of operating systems and associated with production shutdown, and ensuring safety in the shaft during an emergency - eruption.

7. Medical Section performs tasks related to: providing first aid, transport of the injured/sick to the place designated on the rig, e.g.: medical facility and care for the injured/sick.

8. Additional Section is composed of the persons indicated in the alarm schedule. The group includes a person whose job is to verify the presence of people on an offshore unit and communicate the headcount to the Group in Command, as well as caring for the non-member crew.

Any person entering an offshore unit is responsible for:

- timely warning the people directly at risk in the event of danger threatening the crew, the environment or after noticing damage to the equipment of the drilling rig;

- taking appropriate rescue measures, depending on the type of hazard;

- notifying the Rig Manager about danger or the nearest person/manager;

- getting acquainted with the procedures and instructions related to emergencies;

- getting acquainted with the alarm schedule and own emergency number, along with the tasks resulting there from;

- perform tasks in accordance with the number specified in the alarm schedule or instructions issued through loudhailer by the commander.

To ensure effective response and good practice during shipboard emergencies potential emergencies have been identified and procedures that are included in individual operating instructions for emergencies have been determined (each emergency state is determined by a separate instruction incorporated in the plan).

The tasks of the crew and all the people on an offshore unit are specified in the alarm schedule. Each person is assigned an alarm number, placed in the alarm list, which is an integral part of the alarm schedule. In the event of an emergency, offshore unit's crew acts in accordance with the instructions related to the course of action in emergency and the alarm schedule. Groups and sections specified in the alarm schedule are properly prepared, trained in carrying out assigned tasks during emergencies. To ensure adequate preparation to respond to emergencies, drills, exercises and trainings for the crew are conducted regularly.

In the event of emergency on an sea unit requiring immediate action and support from the shipowner, if the action taken by the crew of the unit are not 
enough, immediate action is taken by the company in accordance with the procedure for responding to emergencies. In order to take action appropriate to occurring emergency, emergencies have been identified and relevant procedures have been adequately set out. It should be noted that during the operation in emergency it is essential to save human life, then to protect the marine environment and then property. Taking actions during emergency should be based on the following sequence of events (Fig. 3):

- discuss the safety aspects of the operation during emergency along with the risk assessment performed by the Group in Command presented in the most convenient form and applicable to the situation;

- determine the course of action;

- indication of persons (as defined in the schedule), depending on the type of hazard, responsible for the elimination of the emergency and identification of adequate remedy measures;

- monitoring the intervention;

- the decision on further action and/or support of the actions taken according to available information and analysis of the situation;

- completion of the intervention and cancelling the alarm;

- creation of the report by the Rig Manager.

The fifth element specifies the reporting procedures. Ways of communication and notification must be clearly determined on an offshore unit in the event of an emergency situation to contact the shipowner and the shoreside services. Therefore, the plan includes contact details and a sample report. It should contain the following elements: a way to report, to whom, what happened, where, if there has been contamination of the environment, are there any persons injured. The shipowner provides a line of communication with the ship open 24-hours through the designation of a contact person (Designated Person Ashore). This person maintains 24/7 communication in both during emergency situations and during everyday operation of a drilling rig.

Implementation of the offshore directive. Depending on the location of the event (location of the unit and accessibility to external rescue services), success of the operation depends on quick notification and arrival of external emergency coordinating authorities. 


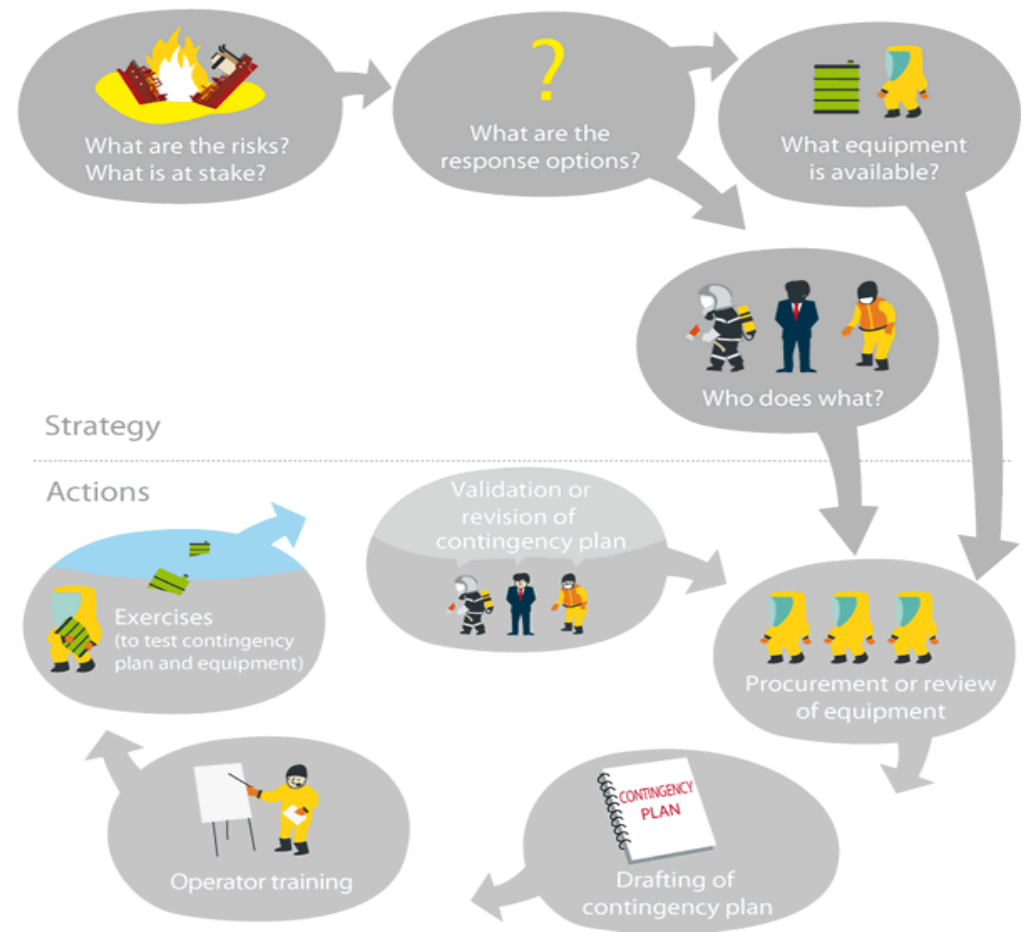

Fig. 3. Procedure sequence [http://www.chemical-pollution.com/index.php (access 05.09.2016)]

\section{IMPLEMENTATION OF DIRECTIVE 2013/30/EU ON SAFETY OF OFFSHORE OIL AND GAS OPERATIONS AND AMENDING DIRECTIVE 2004/35/E}

The aim of the directive 2013/30/EU is to reduce the occurrence of accidents associated with operation related to extraction of oil and natural gas at sea and to limit the effects of these failures as much as possible. The disaster of Deepwater Horizon drilling rig in Gulf of Mexico $^{3}$ has increased awareness concerning the dangers posed by the exploration of the seabed structures. One of the largest marine ecological catastrophes involving the said drilling rig happened on

3 'Deepwater Horizon' drilling rig — belonged to the company Transocean and was rented by BP. It was designed to work at a water depth of 2,500 $\mathrm{m}$ and drilling at the depth of $10,000 \mathrm{~m}$. After two days of rescue operation, the rig sank. 
20 April 2010 in the Gulf of Mexico, while drilling at the depth of $1600 \mathrm{~m}$. As a result of the explosion of the deposit and subsequent fires, 11 crew members died on the rig and about 5 million tons of oil entered the waters, resulting in contamination of the coast states of Louisiana, Mississippi and Florida, killing thousands of animals at the same time. For three months harmful substances were entering the waters of the bay and the oil slick was effectively spread out over the large area by wind and waves breaking through manmade dams. The leakage was not brought to halt until July 2010, when another borehole was made, the pressure in the bed was reduced and the damaged borehole was covered using a 125-tonne containment dome placed over the largest leak. Beside rescue vessels, also planes took part in this operation spraying substance neutralizing the grease floating on the surface. Hundreds of people got involved in clearing the coast and saving animals. As a result of the explosion, in June 2010 the US government banned drilling in the Gulf of Mexico at depths greater than $152 \mathrm{~m}$. The ban was lifted on 12 October 2010 and the process of obtaining permits to carry out drilling works began anew ${ }^{4}$. After the disaster, new rules were established in the USA, which require inspection performed by an independent supervisory authority at every stage of the drilling work. Obtaining new certificates for devices preventing the eruption is also required, as well as constant improvement of safety plans and action plans in case of emergency. The cause of the explosion was attributed to sharp increase in pressure of the fluid, release of hydrocarbon from the poorly secured well and failure of the blowout preventer at this critical moment. The increase in pressure is a common phenomenon in mineral deposits, but it is timely compensated by the circling drilling fluid, which balances the pressure, and in case of insufficient operation, a special safeguards system is activated.

The European Union also established regulations aimed at: '[...] raising the level of safety, including the protection of the marine environment and coastal economies against pollution in particular, stipulating minimum conditions for safe exploration and production of crude oil and natural gas at sea and limiting potential interference of internal energy production within EU, as well as improving the response mechanisms in case of any incidents. This Directive is the environmental pillar of the Integrated Maritime Policy. That policy is relevant to offshore oil and

\footnotetext{
${ }^{4}$ In March 2011 Noble Energy company was the first to receive approval and could proceed, under the new regulations the drilling commenced on April 16, $2010120 \mathrm{~km}$ from the coast of Louisiana. Based on www.wiadomosci.pl [access 14.08.2016].
} 
gas operations as it requires the linking of particular concerns from each economic sector with the general aim of ensuring a comprehensive understanding of the oceans, seas and coastal areas, , seas and coastal areas' ${ }^{5}$.

In Article 14, the document requires the shipowners and operators to develop internal emergency response plans in the event of an emergency at sea on offshore unit s dealing with both drilling and mining. The plans shall be prepared taking into account the major accident risk assessment concerning possible shipboard accidents. This means that the shipowner and operator is required to develop an emergency response plan for incidents that might occur on an offshore unit and to initiate it immediately in an emergency or when there is a risk of its occurrence. For this purpose it will be necessary to:

- maintain proper equipment necessary to respond to an emergency;

- hire suitably qualified shoreside personnel with knowledge and skills for dealing with emergencies occurring at sea;

- ensure that the equipment is ready for immediate use in case of emergency;

- ensure that the plan not only includes the procedures designed to protect the natural environment but also measures to protect the life and health of personnel working on an offshore unit, providing assistance to everyone in need;

- immediate response to any state of emergency - full readiness to take action in order to minimize the effects of the event;

- review and update the plan;

- remain in compliance with external response plan.

\section{CONCLUSIONS}

Safety of an offshore unit is based on three basic factors: the crew prepared to act during emergency, technical means necessary to carry out proper intervention, internal communication on an offshore unit and between the unit and the external services and the shipowner as well as implementation international regulation on borad. The element connecting the foundations of the efficiency and effectiveness are the implemented procedures that govern the conduct of intervention or used as preventive measures. Those discussed selected elements of the emergency response plan are a useful form of implementing them on board an offshore unit.

\footnotetext{
${ }^{5}$ Directive 2013/30/EU Introduction, paragraph 1.
} 
The ISM Code has set an international standard for safety management, both on offshore units and in the shipowner's office in order to ensure the safety and reliability of the unit's operation and prevention of pollution. Accidents occurring at sea involving offshore installations demonstrated weak spots during exploitation of deposits. Therefore, the overriding aim of the Offshore Directive is early prevention of accidents and eliminating vulnerabilities that could lead to an accident.

This article does not exhaust the wide spectrum of issues and encourages further reflection on the improvement of safety in the operation of offshore units. The author of this article will be developing in the succeeding working out.

\section{REFERENCES}

[1] Directive 2004/35/CE of the European Parliament and of the Council of 21 April 2004 on environmental liability with regard to the prevention and remedying of environmental damage.

[2] Directive 2013/30/EU of the European Parliament and of the Council of 12 June 2013 on safety of offshore oil and gas operations and amending directive 2004/35/EC.

[3] Intenational Convention for the Prevention of Pollution from Ships (MARPOL) adopted wit Protocol 1973 and 1997, [in Polish], publ. PRS, 2015.

[4] International Convention for the Safety of Life at Sea (SOLAS), 1974, and its protocol of 1988, [in Polish], publ. PRS, 2015.

[5] International Safety Management Code with guidlines for its implementation, [in Polish], 2014 Edition, IMO, London.

[6] Miler R. K., Safety of the Maritime Tranpsort, [in Polish], PWN, Warszawa 2015.

[7] Resolution A.1072 (28) adopted on 4 December 2013, Revised guidelines for a structure of an integrated system of contingency planning for shipboard emergencies.

[8] Resolution A.852 (20) adopted on 27 of November 1997, Guidelines for a structure of an integrated system of contingency planning for shipboard emergencies.

[9] Resolution MEPC 54 (32), Guidelines for the development of Shipboard Oil Pollution Emergency Plans.

[10] http://www.chemical-pollution.com/index.php [access 05.09.2016].

Received October 2016

Reviewed December 2016 


\begin{abstract}
ALICJA MROZOWSKA
Polish Naval Academy

Śmidowicza 69 Str., 81-127 Gdynia, Poland

e-mail: a.mrozowska@amw.gdynia.pl
\end{abstract}

\title{
STRESZCZENIE
}

W artykule pokazano praktyczne zastosowanie planu reagowania na stany zagrożeń mogących wystąpić na jednostce morskiej. Autorka na podstawie swojego doświadczenia zawodowego omawia plan i przedstawia go na przykładzie ruchomych jednostek górnictwa morskiego zajmujących się eksploracją zasobów pod dnem morskim. W artykule omówiono wymagania dyrektywy 2013/30/UE, która zobowiązuje do wdrożenia planu awaryjnego na jednostkach offshore w celu zapobiegania awariom wynikającym z prowadzonej działalności na obszarach morskich. 